\begin{tabular}{c} 
INDIKATORS Vol 1 (2) (2019) \\
INDIKATORS \\
Journal of Economics and Business \\
http://indicators.iseisemarang.or.id/index.php/jebis \\
\hline
\end{tabular}

\title{
Pengungkapan Faktor Internal dan Eksternal Pada Debitur yang Mempengaruhi Tingkat Kelancaran Pemberian Kredit Usaha Rakyat Mikro
}

\section{Saifudin $^{1 凶}$ Sekar Arum Yunianti ${ }^{2}$}

1,2Jurusan Akuntansi, Fakultas Ekonomi, Universitas Semarang (USM)

\begin{tabular}{|c|c|}
\hline Info Artikel & Abstrak \\
\hline $\begin{array}{l}\text { Sejarah Artikel: } \\
\text { Diterima Mei } 2019 \\
\text { Disetujui Agustus } 2019 \\
\text { Dipublikasikan } \\
\text { November } 2019\end{array}$ & $\begin{array}{l}\text { Penelitian ini bertujuan untuk mengetahui pengaruh faktor internal dan eksternal yang ada pada } \\
\text { debitur terhadap kelancaran dalam pengembalian kredit usaha rakyat mikro. Penelitian ini } \\
\text { merupakan penelitian dengan pendekatan analisa deskriptif kualtitatif dengan menggunakan } \\
\text { triangulasi sumber data yaitu melalui metode dokumentasi dengan mencari informasi data KUR } \\
\text { pada BRI Unit Semarang Barat, kemudian juga dilakukan metode wawancara pada pegawai BRI } \\
\text { dan nasabah BRI untuk mendapatkan informasi yang lebih jelas dan akurat. Penelitian informan }\end{array}$ \\
\hline $\begin{array}{l}\text { Keywords: } \\
\text { Micro Bussiness, KUR, } \\
\text { KUR Mechanism, KUR } \\
\text { Returns }\end{array}$ & $\begin{array}{l}\text { dengan didasarkan pada prinsip kesesuaian (appropriateness) dan kecukupan (adequacy) informasi. } \\
\text { Dasar prinsip informan didalam penelitian ini ada } 4 \text { orang. Dari hasil penelitian menunjukan bahwa } \\
\text { diperlukannya analisis data nasabah dahulu sebelum dilakukannya pencairan atau akad kredit, } \\
\text { faktor internal dan eksternal debitur sebagian besar mampu berpengaruh pada tingkat kelancaran } \\
\text { pengembalian kredit nya kepada Bank BRI. }\end{array}$ \\
\hline
\end{tabular}

\begin{abstract}
This study aims to determine the influence of internal and external factors on debtors on the return of micro bussiness credit. This research is a research with descriptive analysis approach qualitatively by using data source triangles, namely through the documentation method by looking for information on KUR data at the BRI Unit Semarang Barat, then interviewing BRI employees and BRI customers to obtain clearer and more accurate information. The informant's research was based on the principle of appropriateness and adequacy of information. There are 4 people who are based on informants in this research. From the results of the study, it is necessary to analyze customer data before the disbursement or credit agreement, the internal and external factors of the debtor are mostly capable of influencing the level of credit repayment to Bank BRI.
\end{abstract}

\footnotetext{
${ }^{\square}$ Alamat korespondensi:

Jl. Soekarno Hatta, Tlogosari Kulon, Kec. Pedurungan,

Kota Semarang, Jawa Tengah 59160

E-mail: saifudin@usm.ac.id
} 


\section{PENDAHULUAN}

Dalam perkonomian di negara Indonesia, salah satu sektor yang mampu mendorong kemajuan yang cukup baik adalah dalam sektor kewirausahaan yang dikelola oleh masingmasing orang pribadi atau masyarakat pada umumnya, baik di pedesaan hingga di kota-kota besar. Salah satunya yaitu di kota Semarang.

Masyarakat yang ada di kota Semarang banyak yang memilih untuk berwirausaha sendiri atau memiliki usaha yang dikelola sendiri untuk menghasilkan pendapatan bagi kelangsungan hidup yang lebih baik kedepannya, usaha masyarakat yang dikelola sendiri dalam lingkup sektor yang kecil ini bisa disebut juga sebagai usaha mikro.

Usaha mikro merupakan usaha yang dikelola oleh individu atau keluarga atau beberapa orang yang belum memiliki ijin usaha secara lengkap. Pengertian lain dikemukakan Warkum Sumitro, usaha mikro kecil dan menengah adalah usaha yang dilakukan oleh suatu perusahaan dengan tenaga kerja yang digunakan tidak melebihi dari 50 orang. Usaha skala mikro merupakan sebagian besar dari bentuk usaha mikro dan usaha kecil misalnya pedagang kaki lima, kerajinan tangan, usaha souvenir, dan sejenisnya.

Sedangkan menurut UU No. 20 tahun 2008 tentang UMKM bahwa unit usaha mikro adalah usaha produktif yang dimiliki perorangan atau badan usaha perorangan yang memenuhi kriteria usaha mikro sebagaimana yang diatur dalam udang-undang (UU No. 20 tahun 2008). Kriteria usaha mikro yang dimaksud, yaitu (1) Usaha mikro biasanya memiliki hasil penjualan tahunan paling banyak sekitar Rp 100.000.000,-. (2) Kekayaan bersih paling banyak $\mathrm{Rp}$ 50.000.000,- (Departemen Koperasi dan UKM, 2006).

Namun, saat ini kondisi tingkat perekonomian dalam sektor usaha di Indonesia masih kurang memberikan kontribusi yang besar dalam kemajuan negara Indonesia. Salah satu penyebabnya yaitu kurangnya penyediaan modal bagi usahawan untuk mengembangkan usahanya. Oleh karena itu, dibutuhkan lembaga yang mampu memberikan modal bagi para usahawan yang ingin mengembangkan usahanya, salah satu lembaga penjamin modal tersebut ialah "Bank".

Bank adalah lembaga keuangan yang berfungsi sebagai penghimpun dana dari masyarakat dan menyalurkannya kembali kepada masyarakat sebagai modal usaha untuk mengembangkan usahanya dalam bentuk kredit modal usaha.

Di negara Indonesia, terdapat banyak Bank yang mampu memberikan kredit modal bagi usahawan yang ingin mengajukannya. Namun, bank yang paling besar dalam memberikan kontribusi bagi usaha mikro adalah Bank Rakyat Indoensia (BRI). Pinjaman atau kredit ini memiliki arti bahwa kredit itu berbentuk uang atau tagihan yang nilainya diukur dengan uang, kemudian dibuat kesepakatan antara pemberi kredit (kreditur) dengan penerima kredit (debitur) yang mecakup hak dan kewajiban dari masing-masing pihak, jangka waktu, bunga serta sanksi apabila debitur mangkir dari perjanjian yang telah disepakati bersama pada saat akad kredit berlangsung.

Pinjaman yang disalurkan oleh BRI terdiri dari pinjaman kupedes (Kredit Usaha Pedesaan), Briguna (kredit untuk pensiunan, pegawai tetap BRI dan pegawai pada perusahaan lain yang bekerjasama dengan BRI dalam payroll atau sistem penggajian), juga kredit KUR (Kredit Usaha Rakyat).

KUR atau kepanjangannya Kredit Usaha Rakyat adalah kredit unggulan BRI yang digunakan untuk membantu para pengusaha mikro yang membutuhkan tambahan modal untuk pengembangan usahanya.

Dalam hal ini, BRI memberikan kemudahan dalam syarat-syarat untuk mengajukan Kredit KUR yaitu cukup membawa fotokopi identitas diri, melengkapi surat keterangan usaha yang hanya dari RT RW setempat, serta melampirkan jaminan yang akan digunakan untuk agunan di bank. Dengan syarat yang mudah ini, BRI menginginkan bahwa KUR mampu memberikan kontribusi yang positif untuk kemajuan perusahaan juga kemajuan 
bangsa Indonesia. Karena KUR adalah program pemerintah yang dana nya juga berasal dari dana pemerintah yang ditujukan untuk masyarakat yang memiliki usaha mikro dimana pada KUR ini dijamin juga oleh pemerintah melalui lembaga penjaminan kredit Indonesia (Jamkrindo) juga lembaga Asuransi Kredit Indonesia (Askrindo) sebesar 70\% dan sisanya adalah hak pihak bank.

Kredit atau pembiayaan berupa KUR ini diberikan oleh perbankan kepada UMKM yang feasible tapi belum bankable, artinya usaha tersebut memiliki prospek bisnis yang baik dan memiliki kemampuan untuk mengembalikan namun belum pernah mendapatkan pembiayaan modal melalui jasa perbankan. KUR ini bisa sangat meringankan beban calon debitur karena tidak perlu memberikan agunan kepada bank karena kredit ini merupakan pinjaman tanpa agunan dan sudah dijamin oleh pemerintah. Tetapi bukan berarti jika program KUR ini sudah ditanggung pemerintah dapat berjalan lancar dan sesuai dengan harapan yang diinginkan. Beragam risiko pun mulai bermunculan, salah satunya yaitu risiko ketidaklancarannya pengembalian KUR oleh debitur yang dapat mengakibatkan naiknya NPL (Non Performing Loan) bank apabila banyak terjadi kredit macet.

Pada awal muncul nya KUR, BRI memberlakukan di kantor cabang juga di kantor cabang pembantu yang disalurkan untuk ekonomi produktif. Kemudian pada bulan Maret 2008, BRI mulai memberlakukan KUR juga ada di BRI unit. Namun, KUR dalam BRI unit ini hanya dibatasi maksimal plafon kredit hanya sampai dengan Rp.25.000.000,-. PT Bank Rakyat Indonesia Kantor Unit Semarang Barat merupakan unit yang diteliti sebagai kantor unit yang menyalurkan kredit usaha mikro dengan data selama tiga tahun terakhir.

Tabel 1. Jumlah Realisasi KUR pada tahun 2016, 2017 dan 2018

\begin{tabular}{llcl}
\hline Tahun & $\begin{array}{c}\text { Total } \\
\text { Debitur }\end{array}$ & $\begin{array}{c}\text { Kredit Yang } \\
\text { Disalurkan } \\
\mathbf{( R p )}\end{array}$ & $\begin{array}{c}\text { Tingkat } \\
\text { Pertumb } \\
\text { uhan }\end{array}$ \\
\hline 2016 & 450 & 8.636 .000 .000 & \\
2017 & 582 & 5.380 .500 .000 & $0.61 \%$ \\
2018 & $615 \quad$ (sd & 956.466 .000 & $0.46 \%$ \\
& okt & & \\
& 2018) & & \\
\hline
\end{tabular}

Sumber: PT Bank Rakyat Indonesia Unit Semarang Barat (2018) Data Diolah

Berdasarkan data yang diperoleh dari BRI Unit Semarang Barat, menjelaskan bahwa di setiap tahun nya untuk total debitur yang mengajukan kredit Usaha Rakyat selalu mengalami kenaikan. Namun, disisi lain terdapat penurunan kredit yang disalurkan di tahun 2017 dan 2018. Penurunan nominal kredit yang disalurkan dikarenakan yang pengajuan KUR di BRI Unit Semarang Barat cenderung dengan nominal plafond kecil. Jadi tidak ada keseimbangan antara jumlah debitur naik namun total nominal rupiah dalam kredit yang disalurkan mengalami penurunan dari tahun ke tahun selama 2016-2018. Hal ini disebabkan juga oleh beberapa faktor yang menjadi pertimbangan oleh pihak manajemen Bank BRI Unit Semarang Barat tersendiri untuk menentukan siapa saja kreditur yang layak untuk di setujui proses kredit selanjutnya. Kemudian untuk Jumlah data nasabah secara rinci untuk pengajuan dan realisasi KUR di BRI Unit Semarang Barat selama tahun 2018 bisa dilihat pada tabel berikut: 
Tabel 2. Jumlah Pengajuan, Realisasi dan Yang Tidak Terealisasi Tahun 2018

\begin{tabular}{lccc}
\hline \multicolumn{4}{c}{ Tahun 2018} \\
\hline Bulan & $\begin{array}{c}\text { Pengajuan } \\
\text { (Orang) }\end{array}$ & $\begin{array}{c}\text { Realisasi } \\
\text { (Orang) }\end{array}$ & $\begin{array}{c}\text { Yang } \\
\text { Tidak } \\
\text { Teralisasi }\end{array}$ \\
\hline Januari & 65 & 37 & 28 \\
Februari & 56 & 48 & 8 \\
Maret & 69 & 55 & 14 \\
April & 85 & 63 & 22 \\
Mei & 100 & 75 & 25 \\
Juni & 33 & 32 & 1 \\
Juli & 65 & 55 & 10 \\
Agustus & 67 & 56 & 11 \\
September & 50 & 38 & 12 \\
Oktober & 25 & 20 & 5 \\
Jumlah & 615 & 479 & 136 \\
\hline
\end{tabular}

Sumber: PT Bank Rakyat Indonesia Unit Semarang Barat (Data Diolah)

Tabel data diatas menunjukan bahwa ratarata pengajuan di setiap bulan selama tahun 2018 adalah sebanyak 61 orang tetapi untuk rata-rata setiap bulan yang dapat terealisasi hanya 48 orang. Data tersebut menunjukan bahwa banyaknya jumlah pengajuan dengan jumlah data yang terealisasi cukup banyak selisihnya, hal ini disebabkan dengan beberapa faktor yang belum dipenuhi oleh calon kreditur sebagai syarat untuk menerima pinjaman KUR tersebut.

\section{Deskripsi Bank}

Menurut Undang-Undang Perbankan, bank adalah badan usaha yang menghimpun dana dari masyarakat dalam bentuk simpanan dan menyalurkannya kepada masyarakat dalam bentuk kredit dan atau bentuk-bentuk lainnya dalam rangka meningkatkan taraf hidup rakyat banyak.

Usaha Mikro adalah Peluang Usaha Produktif milik orang perorangan atau badan Usaha perorangan yang memenuhi kriteria Usaha Mikro sebagaimana diatur dalam Undang-undang "Usaha Mikro sebagaimana dimaksud menurut Keputusan Menteri Keuangan No.40/KMK.06/2003 tanggal 29 Januari 2003, yaitu usaha produktif milik keluarga atau perorangan Warga Negara Indonesia dan memiliki hasil penjualan paling banyak Rp.100.000.000,00 (seratus juta rupiah) per tahun."

Menurut Rivai, dkk (2005) dalam Pandia (2012) "kredit adalah penyerahan barang, jasa, atau uang dari satu pihak (kreditur) atas dasar kepercayaan kepada pihak lain (debitur) dengan janji membayar dari penerima kredit kepada pemberi kredit pada tanggal yang telah disepakati kedua belah pihak.

Dari pengertian diatas dapat disimpulkan bahwa kata kredit berasal dari bahasa Yunani credere yang berarti kepercayaan yaitu percaya bahwa peminjam dapat membayar kewajibannya sesuai dengan jangka waktu yang telah ditetapkan.

Berdasarkan tujuan penggunaan dana oleh debitur menurut Susilo, Triandaru dan Santoso (2000), kredit dapat dibedakan menjadi (1) Kredit Modal Kerja (KMK). KMK adalah kredit yang digunakan untuk membiayai kebutuhan modal kerja nasabah. (2) Kredit Investasi (KI). Kredit Investasi adalah kredit yang digunakan untuk pengadaan barang modal jangka panjang untuk kegiatan usaha nasabah. (3) Kredit Konsumsi. KK adalah kredit yang digunakan dalam rangka pengadaan barang atau jasa untuk tujuan konsumsi, dan bukan sebagai barang modal dalam kegiatan usaha nasabah.

Menurut Peraturan Menteri Keuangan Nomor 135/PMK.05/2008 adalah kredit atau pembiayaan kepada Usaha Mikro dalam bentuk pemberian modal kerja dan investasi yang didukung fasilitas penjaminan untuk usaha produktif. Dari pengertian diatas dapat disimpulkan bahwa KUR adalah kredit atau pembiayaan kepada Usaha Mikro dalam bentuk pemberian modal kerja dan investasi yang di dukung fasilitas penjaminan untuk usaha produktif. KUR adalah program yang dicanangkan oleh pemerintah namun sumber dananya berasal sepenuhnya dari dana bank.

Menurut Mandala Manurung dan Prathama Rahardja (Uang, Perbankan dan Ekonomi Moneter berbasis Kajian Kontekstual Indonesia 2004; 193) yaitu prinsip 5C: (1) Character (kepribadian) yaitu menyangkut sifat dan kepribadian debitur. (2) Capacity (kemampuan), terkait dengan kemampuan 
debitur untuk melunasi pinjaman (pokok dan bunga). (3) Capital (modal), merupakan kepemilikan modal dan kemampuan nasabah (pengusaha) dalam membiayai perusahaannya. (4) Collateral (agunan), untuk mengetahui resiko yang terjadi dengan tercover agunan ini. Condition of Economy (kondisi ekonomi), pertimbangan atas situasi ekonomi yang sedang terjadi dalam suatu wilayah

Menurut Dendawijaya (2001) faktor yang menjadi pertimbangan bagi pihak bank dalam melakukan seleksi kredit yang dapat mempengaruhi proses kredit yang disetujui pihak bank atau lembaga pemberi pinjaman dapat dikembalikan oleh debitur sesuai dengan jumlah dan waktu yang tepat atau lancar yaitu prinsip 6A: (1) Aspek Yuridis bertujuan untuk mengkaji ketentuan-ketentuan legalitas perusahaan calon penerima kredit. (2) Aspek Pasar dan Pemasaran mengkaji kemungkinan pangsa pasar yang dapat diraih bagi produk/jasa perusahaan yang akan dibiayai oleh kredit. (3) Aspek Teknik bertujuan untuk menilai kemampuan pengusaha dalam mempersiapkan dan melaksanakan pembangunan proyek usaha serta seberapa besar kesiapan teknik dalam menjalankan operasi usahanya. (4) Aspek Manajemen bertujuan untuk mengukur kemampuan dan kecakapan dalam mengelola usaha. (5) Aspek Keuangan bertujuan untuk mengukur kemampuan perusahaan dalam mengelola keuangan. (6) Aspek Sosial Ekonomi.suatu kajian terhadap nilai tambah yang dimiliki perusahaan dari sudut pandang sosial dan makro ekonomi seperti perluasan lapangan kerja dan pendapatan pajak pemerintah.

Menurut Lapia dkk (2017) prinsip dalam analisa debitur yaitu: (1) Return adalah proses Menganalisis hasil yang akan dicapai perusahaan, apakah hasil tersebut mampu digunakan untuk membayar pinjaman dan pengembangan usaha. (2) Repayment Capacity yaitu proses menganalisis berapa lama perusahaan mampu melunasi pinjaman sesuai dengan kemampuan bayarnya. (3) Risk Bearing Ability yaitu proses menganalisis besarnya kemampuan perusahaan debitur untuk menghadapi resiko, apakah perusahaan debitur resiko besar sekali atau kecil. Kemampuan menghadapi resiko erat kaitannya dengan jaminan yang akan diberikan debitur apabila kegagalan pembayaran kredit terjadi

\section{METODE PENELITIAN}

Dalam bisnis perbankan yang menangani perihal kredit, tentunya banyak hal yang menyimpang. Dalam hal ini, pihak perbankan perlu menyaring dan menganalisa data nasabah yang akan mengajukan kredit pada pihak bank. Analisa baik dalam hal kepribadian pada nasabah, hingga analisa pada usaha yang akan dibiayai atau diberi tambahan modal usaha oleh kredit ini.

Metode analisis data yang digunakan dalam penelitian ini adalah menggunakan analisa deskriptif kualitatif, yaitu analisa data yang pengujiannya dalam bentuk keterangan dan pembahasan teoritis yang bertujuan menganalisa hal-hal yang dapat dianalisa bukan dengan angka-angka tetapi dengan teori-teori yang dibuktikan dengan kenyataan yang terjadi, dalam hal ini yang akan dianalisa adalah faktorfaktor internal dan eksternal debitur yang mempengaruhi tingkat kelancaran pengembalian kredit usaha rakyat pada PT Bank Rakyat Indonesia Kantor Unit Semarang Barat.

Penelitian ini dilakukan di PT Bank Rakyat Indonesia Kantor Unit Semarang Barat yang terletak di jalan Jendral Sudirman Ruko Plasa Siliwangi Blok D no 1 kelurahan Karangayu kecamatan Semarang Barat.

Penelitian ini dilakukan pada bulan November 2018 hingga Januari 2019 dengan data yang digunakan berupa sampel data debitur KUR mikro.

Objek yang dikaji dalam penelitian ini berupa variabel yang mempengaruhi tingkat kelancaran kredit usaha rakyat. Adapun objek kajian yang diteliti meliputi:1) Mekanisme penyaluran Kredit Usaha Rakyat di BRI Unit Semarang Barat,2) Prosedur yang wajib dilaksanakan oleh mantri dalam menganalisa kredit,3) Faktor Internal pada debitur yang berpengaruh terhadap tingkat kelancaran pengembalian Kredit Usaha Rakyat di BRI Unit 
Semarang Barat,4) Faktor eksternal pada debitur yang berpengaruh terhadap tingkat kelancaran pengembalian kredit usaha rakyat BRI Unit Semarang Barat.

Jenis Data Penelitian yaitu:1) Data Primer,Data primer merupakan data yang secara langsung diperoleh dari responden yaitu melalui pengusaha dan data dari BRI Unit Semarang Barat. Data yang diperoleh dari pelaku usaha mikro adalah data yang diperoleh dari para pengusaha di segala bidang usaha yang tergolong dalam usaha mikro yang menjalin hubungan kerjasama dengan BRI Unit Semarang Barat dalam hal perkreditan. Selain itu, data primer yang didapat dari BRI Unit Semarang Barat adalah informasi perkreditan yang dilakukan oleh nasabah usaha mikro khusus untuk pengajuan maupun pencairan program Kredit Usaha Rakyat (KUR).

Dengan pertimbangan variabel usia, tingkat pendidikan, laba bersih usaha, lama usaha sudah berjalan, jumlah pinjaman, jangka waktu pinjaman, nilai agunan yang dimiliki, lama menetap di lokasi usaha, kepercayaan dan kesepakatan merupakan hal-hal yang akan ditanyakan kepada nasabah.

Dengan menanyakan hal-hal tersebut maka akan diketahui alasan nasabah dalam melakukan pinjaman KUR di BRI unit Semarang Barat dan alasan pihak BRI untuk menyetujui kredit yang diajukan oleh nasabah yang mengajukan kredit KUR. 2) Data Sekunder, merupakan data-data baik dari internal maupun eksternal perusahaan yang diperoleh seperti pedoman kerja BRI, modulmodul BRI, selebaran-selebaran yang berhubungan dengan kredit di BRI Unit, datadata dari sistem BRI, jurnal-jurnal seperti jurnal skripsi, contoh skripsi, buku pedoman berisi tentang perbankan dan lain-lain.

Prosedur dan Sumber Pengambilan Data: (1) Metode Dokumentasi, dilakukan dengan mempelajari dokumen-dokumen atau data yang dibutuhkan. Metode dokumentasi pada penelitian ini adalah mencari, mencatat, mengumpulkan informasi mengenai KUR Mikro BRI. (2) Wawancara, menurut Dajan (1983), merupakan cara observasi yang bersifat langsung. Wawancara merupakan suatu bentuk cara guna memperoleh keterangan-keterangan, sifatnya adalah fleksibel dan dapat disesuaikan pada kondisi setempat serta individual. Pada penelitian ini menggunakan teknik wawancara tidak tersusun. Wawancara tersebut tidak menggunakan daftar lampiran wawancara. (3) Studi Kepustakaan, Peneliti memperoleh data dari buku-buku pustaka, majalah, jurnal, dan berbagai literatur lainnya yang menjadi referensi serta yang sesuai dengan penelitian.

Teknik analisis data kualitatif ini menggunakan model Miles dan Hubermen (1994). Terdapat 3 (tiga) tahap, yaitu: (1) Tahap Reduksi Data. Mereduksi data berarti merangkum, memilih hal-hal yang pokok, memfokuskan pada hal-hal yang penting, dicari tema dan polanya dan membuang yang tidak perlu. Data yang telah direduksi akan memberikan gambaran yang jelas dan mempermudah penelitian untuk melakukan pengumpulan data selanjutnya, dan mencarinya bila diperlukan.

Dalam penelitian ini, reduksi data dimulai dengan membuat ringkasan dari data yang telah diperoleh, lalu menyisipkan data atau informasi yang tidak relevan, dimana data yang telah direduksi meliputi: (a) Alur Mekanisme Pencairan kredit usaha rakyat pada PT Bank Rakyat Indonesia Kantor Unit Semarang Barat. (b) Fungsi-fungsi atau bagian yang ada di perusahaan berkaitan dengan KUR BRI. (c) Kesesuaian dokumen dan catatan untuk akad kredit. (2) Tahap Display Data. Setelah data direduksi, maka langkah berikutnya adalah mendisplaykan data. Display data dalam penelitian kualitatif bisa dilakukan dalam bentuk: uraian singkat, bagan, hubungan antara kategori, flowchart dan sebagainya. Miles dan Hubermen (1994) menyatakan; "the most frequent form of display data for qualitative research data in the pas hasbeen narative tex" artinya: yang paling sering digunakan untuk menyajikan data dalam penelitian kualitatif dengan teks yang bersifat naratif. Selain dalam bentuk naratif, display data juga berupa grafik, matriks, network jejaring kerja.

Sistem yang akan dikembangkan dalam penelitian ini adalah berupa: (a) Bagan 
mekanisme pencairan dan penyaluran KUR. (b) Rekomendasi dokumen yang akan diajukan. (c) Catatan bagi unit usaha yang meliputi faktor internal dan eksternal dari debitur. (3) Tahap Pemeriksaan Kesimpulan dan Verifikasi Data. Penelitian deskriptif kualitatif mengambil masalah atau memusatkan perhatian kepada masalah-masalah sebagaimana adanya saat penelitian dilaksanakan, hasil penelitian yang kemudian diolah dan dianalisis untuk diambil kesimpulannya. Langkah-langkah untuk menjawab rumusan masalah yaitu: (1) Mendeskripsikan sistem analisa pencairan kredit usaha rakyat pada PT Bank Rakyat Indonesia Kantor Unit Semarang Barat, meliputi : (a) Dokumen-dokumen yang diperlukan dalam akad kredit. (b) Bagian-bagian yang terkait dalam sistem informasi manajemen KUR pada BRI. (c) Bagan alur mekanisme pencairan KUR. (d)
Sistem pengendalian intern BRI yang terkait dengan analisa data debitur.

Hasil temuan di lapangan yang sudah peneliti amati tentang alur pencairan kredit usaha rakyat yang akan dibandingkan dengan teori yang mendukung pada analisa pihak BRI dengan pengendalian intern perusahaan.

\section{HASIL DAN PEMBAHASAN}

Dalam penelitian ini adalah menggunakan analisis deskriptif kualitatif dimana, data diambil dari dokumen-dokumen yang bersumber dari PT Bank Rakyat Indonesia Kantor Unit Semarang Barat dengan mengambil salah satu data debitur yang dijadikan sampel penelitian. Selain data debitur, juga dilakukan proses wawancara mengenai variabel yang dibahas dalam penelitian ini kepada 4 narasumber informasi.

Tabel 3. Hasil Penelitian

\begin{tabular}{|c|c|c|c|c|c|c|}
\hline No & Faktor yang berpengaruh & Hesti & Ika & Adel & Yusnia & Kesimpulan \\
\hline 1 & Usia & + & + & - & + & + \\
\hline 2 & Tingkat Pendidikan & + & + & - & + & + \\
\hline 3 & Kepercayaan & - & - & - & + & - \\
\hline 4 & Kesepakatan & + & + & + & + & + \\
\hline 5 & Jumlah Tanggungan Keluarga & + & + & + & + & + \\
\hline 6 & Laba Bersih Usaha & + & + & + & + & + \\
\hline 7 & Lama Usaha & + & + & + & + & + \\
\hline 8 & Jumlah Pinjaman & + & + & + & + & + \\
\hline 9 & Jangka Waktu Pinjaman & + & + & + & + & + \\
\hline 10 & Nilai Agunan & - & - & - & + & - \\
\hline
\end{tabular}

Hasil pengolahan data menunjukkan bahwa hasil dari wawancara sebagai berikut: (1) Faktor Internal Pada debitur yang mempengaruhi tingkat kelancaran pengembalian kredit meliputi: (a) Usia. Usia berkaitan dengan tingkat kematangan seseorang serta pengalaman yang dimiliki orang tersebut dalam menjalankan usaha (Astri, 2011:24). Dengan kata lain bahwa usia akan mempengaruhi keberanian pengusaha dalam mengambil keputusan. Oleh karena itu diduga semakin tua usia seseorang maka semakin baik pula kebijaksanaannya dalam mengambil keputusan serta lebih rasional. (Rusdani (2010:34).
Dari hasil penelitian yang dilakukan pada BRI Unit Semarang Barat, menjelaskan bahwa usia yang dikategorikan sebagai usia yang matang dalam meminjam atau mengajukan kredit adalah usia diatas 21 tahun.

Terkadang masyarakat berpikir bahwa seseorang yang berada diusia 17 tahun atau seseorang yang sudah memiliki KTP, itu dikatakan seseorang yang dewasa. Akan tetapi, berbeda dengan penilaian pihak bank, yang membuat peraturan bahwa usia 21 tahun lah yang layak untuk dikatakan sebagai usia yang matang dan layak untuk mengajukan kredit. 
Hal tersebut dikarenakan bahwa usia 2140 tahun adalah usia produktif, dimana seseorang akan cenderung lebih giat dalam bekerja. Di usia itu pun juga diketahui merupakan usia dengan tingkat kematangan seseorang telah teruji. Rasa tanggung jawab pada diri sendiri dan pada orang lain akan muncul dan mulai terlihat di usia tersebut.

Menurut penelitian yang dilakukan pada BRI Unit Semarang Barat dengan metode wawancara keempat responden, disimpulkan bahwa memang usia yang dewasa yang disetujui untuk mengajukan kredit adalah usia 21tahun, dan faktor usia ini berpengaruh terhadap kelancaran dalam pengembalian kredit, karena semakin dewasa seseorang maka tingkat kualitas kelancaran kreditnya pun bisa terjamin. (b) Tingkat Pendidikan. Pendidikan adalah perubahan sikap dan tata laku seseorang dalam mendewasakan manusia melalui upaya pengajaran dan pelatihan.

Tingkat pendidikan diduga menjadi salah satu faktor yang mempengaruhi pengembalian kredit karena faktor ini mempengaruhi karakter individu (character). Hasil wawancara mengungkapkan bahwa semakin tinggi tingkat pendidikan seseorang maka pengetahuan dan wawasan yang dimiliki juga semakin luas. Hal ini juga mencakup pengetahuan akan potensi diri dan usahanya sehingga dapat meningkatkan produktivitas, menaikkan pendapatan dan pengembalian kredit menjadi lancar. Sebaliknya, semakin rendah tingkat pendidikannya mengakibatkan kemampuan menyerap informasi dan pasar semakin lamban, maka usahausahanya akan bergerak lamban pula (Sandy, 2012:39). (c) Kepercayaan. Kepercayaan adalah kemauan seseorang untuk bertumpu pada orang lain dimana kita memiliki keyakinan padanya tentang suatu hal. Kepercayaan dalam kredit ini akan diberikan pada saat akad kredit agar dapat mengembalikan sesuai dengan persyaratan yang disepakati bersama.

Namun, sesuai dengan hasil penelitian yang dilakukan, kepercayaan ini tidak berpengaruh terhadap tingkat kelancaran pengembalian kredit. Karena jika hanya rasa percaya terhadap perilaku, tutur kata yang baik dari seorang debitur pada saat awal pengajuan kredit, sama sekali tidak akan mempengaruhi tingkat kelancaran dalam pengembalian kreditnya. Karena disisi lain bisa jadi debitur tersebut hanya baik di awal saja, namun jika sudah di cairkan kreditnya bisa berubah pikiran dan berlainan dengan sikap pada saat awal pengajuan. (d) Kesepakatan. Kesepakatan adalah suatu hal yang terbentuk dari rangkaian proses-proses yang bisa saja termasuk ke dalam suatu perundingan maupun suatu pemikiran pemikiran yang matang terhadap suatu hal yang berkaitan dengan kepentingan pribadi.

Kesepakatan dalam kredit KUR ini adalah kesepakatan yang terjadi pada diri debitur, dimana ia harus meyakinkan diri pada peraturan perkreditan yang telah dipaparkan pada saat awal pengajuan kredit. Baik kesepakatan mengenai tingkat bunga, biaya administrasi, biaya asuransi yang wajib diikuti oleh debitur peminjam kredit KUR, hingga peraturan tentang agunan yang semestinya bisa mengcover pinjaman tersebut dengan menandatangani kertas hutang bermaterai yang artinya bahwa setelah tanda tangan bermaterai ini nasabah bersedia mengikatkan diri pada BRI untuk menjalankan hutang dengan mengangsurnya sesuai ketentuan hingga lunas yang berdasarkan pada keterikatan hukum. Sehingga hasil wawancara pada keempat responden ini menunjukkan bahwa kesepakatan mempengaruhi tingkat kelancaran pengembalian KUR.

(2) Faktor Eksternal pada debitur yang mempengaruhi tingkat kelancaran pengembalian kredit meliputi: (a) Jumlah Tanggungan Keluarga. Jumlah Tanggungan Keluarga merupakan salah satu faktor eksternal penentu dalam kelancaran pengembalian kredit oleh seorang debitur.

Jumlah tanggungan keluarga ini berpengaruh positif terhadap tingkat kelancaran pengembalian kredit usaha rakyat oleh debitur yang mengajukan. Karena jumlah tanggungan keluarga ini akan menjadi biaya yang harus dikeluarkan untuk kebutuhan sehari-hari yang wajib dilakukan. Karena keluarga merupakan aset pertama dari sebuah kehidupan. Maka 
dalam hidup berdampingan yang membutuhkan keluarga ini wajib pula untuk memenuhi kebutuhan yang diinginkan atau yang memang dibutuhkan oleh keluarga dari seorang debitur tersebut. Semakin tinggi biaya hidup yang ditanggung oleh seorang debitur untuk keluarganya, akan berpengaruh terhadap pengurangan pendapatan dari hasil usaha, maka bagaimana cara pun harus pandai dilakukan oleh debitur agar angsuran kreditnya pada BRI tetap berjalan semestinya sesuai waktu yang ditentukan, juga mampu memenuhi kebutuhan keluarga yang ditanggung olehnya. Lebih baik pula jika seorang debitur tersebut perlu untuk mempertimbangkan jumlah anak yang akan ikut hidup bersamanya agar tidak menimbulkan kebutuhan hidup yang semakin meningkat karena terlalu banyak jumlah anak yang ditanggungnya. (b) Laba Bersih Usaha

Laba bersih usaha adalah kelebihan seluruh pendapatan dalam suatu periode tertentu setelah dikurangi dengan biaya-biaya yang menjadi tanggungan perusahaan demi kelangsungan operasional usahanya.

Menurut Luh (2013:36) menjelaskan bahwa laba bersih diduga berpengaruh positif terhadap kelancaran pengembalian kredit karena semakin tinggi keuntungan dari usaha yang dijalankan maka kapabilitas dalam mengelola usaha semakin baik dan kemampuan membayar angsuran dan beban bunga semakin tinggi sehingga peluang pengembalian kredit secara lancar juga semakin besar.

Lalu dalam hasil penelitian yang dilakukan di BRI Unit Semarang Barat dengan melalui wawancara keempat responden, maka dijelaskan bahwa laba bersih usaha para pengusaha mikro atau debitur yang mengajukan kredit tersebut sangat berpengaruh terhadap tingkat kelancaran pengembalian kredit. Dengan kata lain, bahwa laba usaha ini dapat didapatkan oleh pihak bank dari penjelasan debitur. Penjelasan secara rinci mengenai kegiatan operasional usaha debitur tersebut. Dari mulai modal awal yang dikeluarkan, pendapatan per hari yang dikalkulasikan hingga satu bulan, dan biaya-biaya yang dibutuhkan dalam menhelola usaha tersebut per hari yang dihitung hingga satu bulan tertentu.

Masa penilaian laba usaha debitur ini biasanya yang dinlai oleh BRI adalah laporan keuangan 3 bulan terakhir. (c) Lama Usaha . Pengertian Lama Usaha yang dimaksud dalam hal ini adalah lama usaha berkaitan dengan pengalaman usaha yang dimiliki. Semakin banyak pengalaman yang dimiliki maka semakin baik kemampuan seseorang dalam mengelola usahanya (Cahyono : 1995). Lama pembukaan usaha dapat mempengaruhi tingkat pendapatan, lamanya seorang pelaku usaha atau bisnis menekuni bidang usahanya akan mempengaruhi produktivitasnya (kemampuan atau keahliannya), sehingga dapat menambah efisiensi dan mampu menekan biaya produksi lebih kecil dari pada hasil penjualan. Semakin lama menekuni bidang usahanya maka akan semakin paham sehingga mampu meningkatkan pengetahuan tentang selera maupun perilaku konsumen. Keterampilan dalam menjualkan atau kemampuan dalam promosi yang baik juga akan semakin bertambah dan semakin banyak pula relasi bisnis maupun pelanggan yang berhasil di jaring (Wicaksono, 2011). Keahlian keusahawaan merupakan kemampuan yang dimiliki seseorang untuk mengorganisasikan dan menggunakan faktor-faktor lain dalam kegiatan memproduksi barang dan jasa yang diperlukan masyarakat (Sukirno, 1994). Sehingga dalam hasil penelitian yang dlakukan, dijelaskan bahwa lama usaha berpengaruh signifikan terhadap tingkat kelancaran pengembalian kredit usaha rakyat. (d) Jumlah Pinjaman. Jumlah pinjaman merupakan besarnya kredit yang diajukan oleh debitur apakah sesuai dengan kemampuannya dalam mengembalikan kredit dengan mempertimbangkan jangka waktu dan besar pinjaman, yang kemudian akan diberikan oleh Bank kepada pengusaha usaha mikro dengan ketentuan tertentu. Tujuan kredit adalah untuk membantu permodalan usaha mikro. Dengan bertambahnya modal yang dimiliki diharapkan usaha mikro dapat mengembangkan usahanya dan meningkatkan produktifitas sehingga meningkatkan peluang kelancaran pengembalian kredit (Mukti, 2007:39). 
Dengan demikian berdasarkan hasil wawancara yang dilakukan pada empat responden dijelaskan bahwa jumlah pinjaman berpengaruh positif terhadap pengembalian kredit, karena pihak bank menilai kemampuan plafond kredit yang diajukan dengan mempertimbangkan kemampuan seorang debitur terhadap jumlah angsuran per bulan, yang disesuaikan dengan laporan keuangan atau tingkat laba yang didapatkan oleh debitur dalam mengelola usahanya. Dengan memperhitungkan sebesar $70 \%$ dari hasil laba bersih usaha untuk maksimal jumlah angsuran yang akan diangsur per bulan oleh debitur. Sisanya sebesar 30\% tersebut bisa digunakan untuk kebutuhan lainlain oleh debitur. (a) Jangka Waktu Pinjaman. Jangka Waktu Pinjaman merupakan waktu jatuh tempo debitur untuk melunasi angsuran pokok beserta bunga pinjaman. Jangka waktu pinjaman akan mempengaruhi jumlah angsuran dan bunga yang akan dibayarkan setiap bulan (Sandy, 2012:41). Semakin lama jangka waktu pinjaman akan meringankan angsuran dan bunga yang dibayarkan setiap bulannya.

Oleh karena itu, debitur wajib mempertimbangkan lebih matang jangka waktu dan plafond kredit yang diajukan dengan tingkat kemampuan dalam membayar per bulan, dengan petimbangan pendapatan tiap bulan jika dikurangi untuk mengangsur pinjaman apakah kebutuhan yang lain tercukupi atau tidak dll.

Disisi lain, semakin lama jangka waktu pengembalian kredit yang diajukan debitur maka akan menurunkan perputaran dana dan likuiditas bank, sehingga bank akan lebih mempertimbangkan kredit dengan jangka waktu pinjaman yang lama (Luh, 2013:38). Dalam hal ini, BRI memberikan keputusan bahwa Kredit KUR ini dapat diajukan dengan maksimal plafond Rp.25.000.000 dengan jangka waktu maksimal 36bulan, diatas plafond dan jangka waktu yang ditentukan, BRI Unit Semarang Barat tidak akan memproses pengajuan kredit lebih lanjut.

Berdasarkan penjelasan diatas menjelaskan bahwa hasil dari wawancara yang dilakukan, jangka waktu pengembalian kredit ini berpengaruh pada tingkat klancaran pengembalian kredit. (b) Nilai Agunan. Jaminan atau agunan adalah aset pihak peminjam yang dijanjikan kepada pemberi pinjaman (Bank). Jika peminjam tidak dapat mengembalikan pinjaman tersebut, maka pihak pemberi pinjaman dapat memiliki agunan tersebut atau istilah lain, pihak Bank akan menyita aset seorang peminjam yang dijaminkan pada Bank. Dalam analisa kredit, jaminan sering menjadi faktor penting untuk meningkatkan nilai kredit. Nilai agunan ini adalah salah satu penentu besarnya pinjaman yang layak diberikan pada debitur agar jika suatu hari nanti debitur tidak mampu mengembalikan kreditnya, setidaknya pihak Bank bisa menjualkan jaminan tersebut pada masyarakat umum minimal sesuai plafond yang dibutuhkan oleh Bank untuk menutup pinjaman debitur tersebut. Sehingga pihak Bank tidak akan merasa dirugikan atas hal ini. Sehingga hasil dari penelitian pada BRI Unit Semarang Barat disimpulkan bahwa nilai jaminan sebenarnya tidak begitu mengikat dalam analisa kredit atau dengan kata lain yaitu nilai agunan ini tidak berpengaruh pada tingkat kelancaran pengembalian kredit.

Namun peraturan manajemen bank BRI agar debitur memiliki rasa tanggung jawab untuk melunasi pinjaman sesuai dengan waktu yang telah disepakati, maka jaminan tersebut dikemukakan pada debitur bahwa nilai jaminan harus mengandung nilai jual yang sesuai dengan jumlah kredit yang diajukan pada saat itu.

\section{SIMPULAN}

Berdasarkan hasil wawancara terhadap keempat responden didapatkan simpulan bahwa: 1) Variabel yang berpengaruh pada tingkat kelancaran pengembalian kredit yaitu variabel usia, tingkat pendidikan, kesepakatan, jumlah tanggungan keluarga, laba bersih usaha, lama usaha, jumlah pinjaman dan jangka waktu pinjaman,2)Variabel yang tidak berpengaruh terhadap tingkat kelancaran pengembalian kredit yaitu variabel kepercayaan dan nilai agunan.

Implikasi yang didapatkan adalah sebagai berikut: 1)Dalam menganalisa kredit sebelum pencairan kredit maka seorang responden kunci 
yaitu mantri yang memiliki peranan pokok dalam hal ini harus teliti dan jeli dengan sikap debitur, apakah ia adalah seseorang yang bertanggung jawab atau tidak. Hal ini dapat dipraktekkan dengan cara pada saat OTS (On The Spot) ke rumah dan tempat usaha debitur perlu untuk mencari informan-informan diluar dari diri atau keluarga debitur itu sendiri misalnya tetangga sebelah hingga tetangga yang cukup jauh dari tempat tinggal calon debitur namun masih dalam lingkup daerah yang sama dan saling kenal atau mengetahui satu sama lain.

2) Disamping itu, mantri juga harus cukup tegas dalam melakukan penilaian BI Checking data calon debitur dan suami/istri debitur. Jika calon debitur sebelumnya pernah memiliki fasilitas pinjaman di bank lain meskipun sudah lunas, perlu dilihat kolektibilitasnya dahulu. Apakah lancar (K1) ataukah pernah menunggak. Hal ini cukup signifikan untuk mengetahui sikap dan rasa tanggung jawab seorang calon debitur dari melihat pinjaman sebelumnya di bank lain.

Dalam praktek dilapangan, sering terjadi karena terlalu sibuk mengejar angka target yang ditetapkan manajemen pusat, maka seorang mantri sering mengabaikan hal itu, dan hanya menganggap angin lalu dan berprinsip yang penting pada saat mau pencairan kredit sudah dilunasi dulu pinjaman-pinjaman di bank atau instansi keuangan lainnya.3) Bagi peneliti yang akan mengambil tema yang sama, sebaiknya dapat menggunakan variabel-variabel lain untuk mengukur tingkat kelancaran pengembalian kredit atau dapat menambah dan mengganti jumlah sampel yang digunakan.

\section{DAFTAR PUSTAKA}

Febriand, Andy, 2013, "Pengertian dan Sejarah Bank", UNS, Solo.

Fitria, Nurul dan Raina, 2012, "Analisis Kebijakan Pemberian Kredit dan Pengaruh Non Performing Loan Terhadap Loan To Deposit Ratio", Jurnal Ekonomi dan Keuangan Vol 1 No 1.
Hasibuan, Rusdani, 2010, "Analisis Faktor-Faktor yang Mempengaruhi Tingkat Kredit Macet Pada Kredit Usaha Pedesaan (Kupedes) yang Terkait Sektor Agribisnis" Institut Pertanian Bogor, Bogor.

Ikatan Bankir Indonesia, 2018, "Bisnis Kredit Perbankan", PT Gramedia Pustaka Utama, Jakarta

Kasmir, 2010, "Bank dan Lembaga Keuangan Lainnya" PT Raja Grafindo Indonesia, Jakarta

Kholifah, Siti dan I Wayan Suyadnya, 2017, “Metode Penelitian Kualitatif Berbagi Pengalaman Dari Lapangan", PT Raja Grafindo Persada : Depok

Lapia, Stevani Helena, dkk, 2016, “Analisis Kelayakan Pemberian Kredit Usaha Mikro Dalam Upaya Mengantisipasi Terjadinya Kredit Bermasalah", Universitas Brawijaya, Malang

Liana, Vivin, 2017, "Faktor-Faktor Pendorong Pengusaha UMKM Dalam Mengambil atau Menggunakan Kredit Usaha Rakyat (KUR) BRI di Kabupaten Sragen", Universitas PGRI, Madiun.

Lubis, Anna Maria dan Dwi Rachmina, 2011, "Faktor-Faktor Yang Mempengaruhi Realisasi dan Pengembalian Kredit Usaha Rakyat", Departemen Agribisnis Institut Pertanian Bogor, Bogor

Ramli, Muhammad, 2018, "Akuntansi Perbankan", Ghalia Indonesia : Bogor

Rochmawati, Miranda, 2012, "Analisis Faktor Yang Mempengaruhi Tingkat Pengembalian KUR", Universitas Brawijaya, Malang

Saraswati, Lukyta dan I Ketut Yadnyana, 2014, "Pengaruh Struktur Pengendakian Intern Terhadap Kelancaran Pengembalian Kredit Pada Koperasi Simpan Pinjam di Kota Denpasar", Universitas Udayana, Bali.

Sinungan, Muchdarsyah, 1979, "kredit", Yagrat, Jakarta

Tohir, Noel Chabannel, 2012, "Panduan Lengkap Menjadi Account Officer", PT Elex Media Komputindo : Jakarta

Zakky, 2018, "Jenis-Jenis Bank di Indonesia", Zona Referensi Ilmu Pengetahuan Umum, Jakarta. 